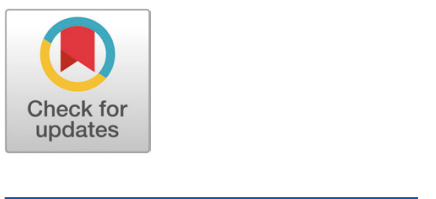

Received: Feb 5, 2020

Revised: Apr 16, 2020

Accepted: Apr 27, 2020

\#These authors contributed equally to this work.

*Corresponding author Byung Ki Park

Department of Animal Science, Kangwon National University,

Chuncheon 24341, Korea.

Tel: +82-33-250-8623

E-mail: animalpark@hanmail.net

Copyright $(\subset 2020$ Korean Society of Animal Sciences and Technology.

This is an Open Access article distributed under the terms of the Creative Commons Attribution

Non-Commercial License (http:// creativecommons.org/licenses/bync/4.0/) which permits unrestricted non-commercial use, distribution, and reproduction in any medium, provided the original work is properly cited.

ORCID

Jun Sang Ahn

https://orcid.org/0000-0001-7362-9270 JongSuh Shin

https://orcid.org/0000-0003-1148-2562 MinJi Kim

https://orcid.org/0000-0001-6485-1718 GiHwal Son

https://orcid.org/0000-0001-6406-0262

DeokYun Gil

https://orcid.org/0000-0002-7801-7967

EungGi Kwon

https://orcid.org/0000-0002-5585-5909

ByungKi Park

https://orcid.org/0000-0001-5469-2012

Competing interests

No potential conflict of interest relevant to this article was reported.

\section{A study on the optimal thickness of corn flakes produced by using the pressurized steam chamber}

\author{
Jun-Sang Ahn ${ }^{1 \#}$, Jong-Suh Shin ${ }^{2 \#}$, Min-Ji Kim², Gi-Hwal Son ${ }^{2}$, Deok-Yun Gil \\ Eung-Gi Kwon ${ }^{1}$ and Byung-Ki Park ${ }^{2 *}$ \\ ${ }^{1}$ Hanwoo Research Institute, National Institute of Animal Science, RDA, Pyeongchang 25340, Korea \\ ${ }^{2}$ Department of Animal Science, Kangwon National University, Chuncheon 24341, Korea
}

\section{Abstract}

This study was conducted to evaluate the effect of the thickness of corn flakes produced by pressurized steam chamber (PSC) on rumen fermentation characteristics and nutrient degradability in Hanwoo and Holstein cows. Corn flakes were treated by PSC, in three groups based on corn flake thickness: $<2.5 \mathrm{~mm}$ (T1), 2.5-3.0 mm (T2), and $>3.0 \mathrm{~mm}$ (T3). Corn flake thickness significantly influenced $\mathrm{pH}(p<0.01)$ and propionate concentration $(p<0.05)$ and slightly but not significantly influenced acetate, butyrate, and total-volatile fatty acids (T-VFA) concentrations. The dry matter (DM) degradability increased significantly with a reduction in corn flake thickness $(p<0.01)$, being significantly greater in T1 and T2 than T3 groups $(p<0.01)$ and similar between T1 and T2 groups throughout whole incubation time. Also, starch degradability was the lowest in T3 groups than others $(p<0.01)$. Thus, the present results showed that considering the production efficiency and economic feasibility, the optimal thickness of corn flakes produced in a PSC is recommended to be $2.5-3.0 \mathrm{~mm}$.

Keywords: Pressurized steam chamber, Corn flake, Thickness, Dry matter degradability, Starch degradability

\section{INTRODUCTION}

In general, corn flakes is produced using a steam chamber. Recently, the production of corn flakes using a pressurized steam chamber (PSC) is increasing in korea. PSC is a system wherein a pressure device is placed in the existing steam chamber. The use of PSC effectively reduce the time for processing, energy, and cost of corn flake production. However, few studies have assessed conditions including chamber temperature, time, and thickness compared to those investigating older steam chambers of historical value [1].

Zinn et al. [2] reported that the quality standards for corn flakes include thickness, density, starch solubility, and enzyme activity. Among these factors, thickness and density in particular are the ones that have a great influence on the quality of corn flakes [3]. Schwandt [4] reported that with a reduction in the space between rolls, corn flake density decreased proportionately with thickness, thereby increasing levels of digestible starch. Furthermore, Plascencia and Zinn [5] and Son et al. [6] reported that dry matter $(\mathrm{DM})$ and starch digestibility increased with a reduction in corn 
Funding sources

Not applicable.

Acknowledgements

This research was supported by the "RDA

Research Associate Fellowship Program"

Rural Development Administration, Korea.

Availability of data and material

Upon reasonable request, the datasets

of this study can be available from the

corresponding author.

Authors' contributions

Conceptualization: Shin JS, Park BK

Data curation: Kim MJ, Gil DY.

Formal analysis: Son GH, Gil DY.

Methodology: Ahn JS, Kwon EG.

Software: Son GH.

Validation: Shin JS

Investigation: Kim MJ, Son GH.

Writing - original draft: Ahn JS.

Writing - review \& editing: Shin JS, Kwon EG, Park BK.

Ethics approval and consent to participate The experimental animals used in this study were approved by the Animal Experiment Ethics Committee of Kangwon National University (KNU No: KIACUC-16-0010). flake thickness. However, excessive low thickness of corn flakes reportedly increased the energy costs [7], increased loss of corn [8], cracking of corn, or excessive flour production [9,10].

The availability of starch in the rumen can vary depending on the thickness of corn flakes. In addition, the productivity (production efficiency, manufacturing cost, etc.) of corn flakes can be influenced by their thickness. Therefore, it is important to determine the optimal thickness of corn flakes produced using the PSC; However, there has been few or no study on the effect of cornflake thickness that produced by PSC on the fermentation properties and nutrient digestibility of rumen. Thus, This study was conducted to evaluate the effect of the thickness of corn flakes produced in a PSC on fermentation characteristics and nutrient degradability in rumen.

\section{MATERIALS AND METHODS}

The experimental animals used in this study were approved by the Animal Experiment Ethics Committee of Kangwon National University (KNU No: KIACUC-16-0010).

\section{Experimental animals and treatments}

In this study, six cows with transplanted ruminal cannula were used for the experimental animals. Three Hanwoo cows (average body weight, $335.5 \pm 41.2 \mathrm{~kg}$ ) and three Holstein cows (average body weight, $425.6 \pm 37.5 \mathrm{~kg}$ ).

Corn flakes produced by PSC were treated into three groups based on their thickness: $<2.5 \mathrm{~mm}$ (T1), 2.5-3.0 mm (T2), and > $3.0 \mathrm{~mm}$ (T3). The processing conditions for corn flakes in the PSC were as follows: $1.5 \mathrm{~atm}, 110^{\circ} \mathrm{C}, 750 \mathrm{~s}$. Chemical compositions and gelatinization of corn flakes are shown in Table 1 and Fig. 1.

\section{Characteristics of in vitro ruminal fermentation}

Rumen fluid was collected from the rumen cannula, filtered through four layers of gauze, and stored in a thermos flask at $39^{\circ} \mathrm{C}$. Thereafter, $\mathrm{O}_{2}$-free $\mathrm{CO}_{2}$ gas was injected for $1 \mathrm{~min}$ to eliminate air at the flask, and allowed to stand for $30 \mathrm{~min}$ in an incubator at $39^{\circ} \mathrm{C}$ to be used for inoculum for in vitro.

In vitro culture solutions were prepared by mixing $4,788 \mathrm{~mL}$ of buffer solution [11] with 1,200 $\mathrm{mL}$ of rumen inoculum. The prepared in vitro culture solutions were divided into three glass jars $(4 \mathrm{~L})$ by $2 \mathrm{~L}$ each, and sample bags $(15 \mathrm{~g})$ was added according to the thickness treatment, and then $\mathrm{CO}_{2}$ gas without $\mathrm{O}_{2}$ was injected. Incubation was carried out for $3,6,12$, and $24 \mathrm{~h}$ in a $39^{\circ} \mathrm{C}$ incubator, and three times of $15 \mathrm{~mL}$ of culture solutions was collected for each hour in jar and used to analyze rumen fermentation characteristics. A total of three repetition experiments were performed in the

Table 1. Chemical composition of corn flakes (dry matter basis)

\begin{tabular}{lrrr}
\hline \multirow{2}{*}{ Item } & \multicolumn{3}{c}{ Treatments ${ }^{1)}$} \\
\cline { 2 - 4 } & \multicolumn{1}{c}{ T1 } & \multicolumn{1}{c}{ T2 } & \multicolumn{1}{c}{ T3 } \\
\hline Dry matter (\%) & $89.22 \pm 0.98$ & $88.20 \pm 1.32$ & $89.37 \pm 0.25$ \\
Crude protein (\%) & $8.35 \pm 0.14$ & $8.49 \pm 0.59$ & $7.72 \pm 1.29$ \\
Ether extract (\%) & $2.90 \pm 0.06$ & $3.30 \pm 0.72$ & $3.87 \pm 0.38$ \\
Crude ash (\%) & $1.39 \pm 0.14$ & $1.78 \pm 0.05$ & $1.48 \pm 0.05$ \\
NDF (\%) & $10.58 \pm 0.11$ & $10.38 \pm 0.61$ & $10.17 \pm 0.52$ \\
NFC (\%) & $76.78 \pm 0.06$ & $76.06 \pm 0.31$ & $76.77 \pm 0.43$ \\
Starch (\%) & $54.35 \pm 0.35$ & $53.95 \pm 0.42$ & $54.11 \pm 0.16$ \\
\hline
\end{tabular}

${ }^{11}$ Treatments : $\mathrm{T} 1<2.5 \mathrm{~mm}, \mathrm{~T} 2=2.5-3.0 \mathrm{~mm}$, and $\mathrm{T} 3>3.0 \mathrm{~mm}$

$\mathrm{NDF}$, neutral detergent fiber; NFC, non fiber carbohydrates. 


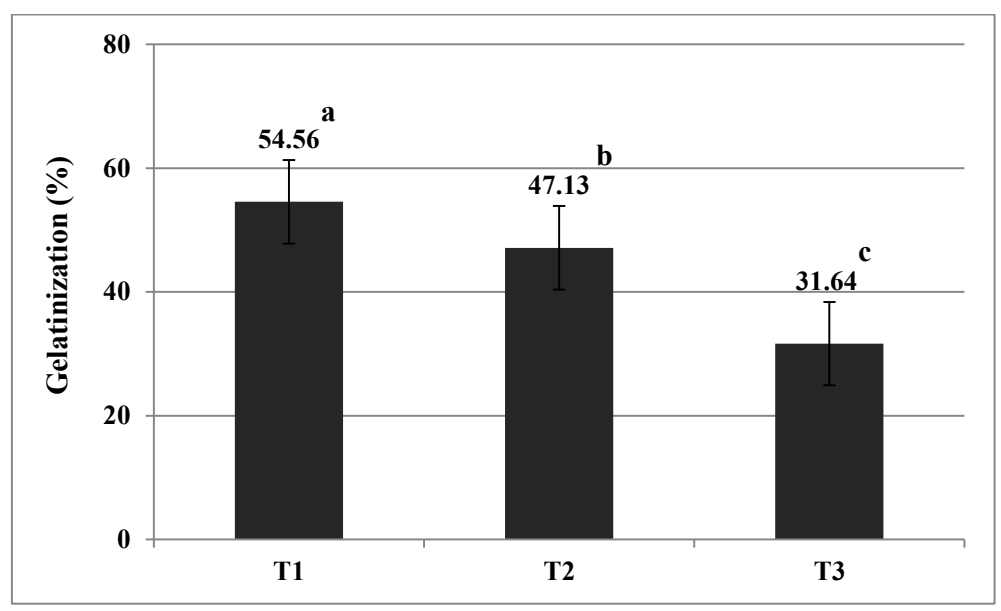

Fig. 1. Changes in gelatinization by the thickness of corn flakes using the pressurized steam chamber. Corn flakes: $\mathrm{T} 1<2.5 \mathrm{~mm}, \mathrm{~T} 2=2.5-3.0 \mathrm{~mm}$, and T3 $>3.0 \mathrm{~mm} .{ }^{\mathrm{a}-\mathrm{c}}$ Means without same superscripts within a column are significantly different $(p<0.01)$.

same method.

\section{In situ degradability of nutrient}

For in situ experiment, corn flakes were measured in $5 \mathrm{~g}$ each according to the thickness group and placed in a nylon bag $(5 \times 10 \mathrm{~cm})$. Three nylon bags were produced for each treatment per incubation time, and the nylon bags were placed in a mesh, and then inserted into the rumen cannula. In situ experiments were incubated for $24 \mathrm{~h}$, and meshes were collected through cannula every 3, 6,12, and $24 \mathrm{~h}$ respectively. The nylon bag was washed until clear water was obtained, and then dried in a $70^{\circ} \mathrm{C}$ forced dry oven for $48 \mathrm{~h}$. A total of theree repetition experiments were performed in the same method.

\section{MEASUREMENTS AND ANALYSIS}

Chemical composition of corn flakes were analyzed in accordance with the methods of the AOAC [12], and the contents of neutral detergent fiber (NDF) were measured in accordance with the method of Goering and Van Soest [13]. The contents of non-fiber carbohydrates (NFC) were determined using the following equation:

NFC $(\%)=100-($ moisture $[\%]+$ crude protein $[\%]+$ crude ash [\%] + ether extract [\%] + NDF [\%]).

Starch concentration was determined according to the standard feed analysis method [14], and the gelatinization was analyzed method for titration of Korean food standards codex [15].

The rumen $\mathrm{pH}$ was analyzed using a $\mathrm{pH}$ meter (Corning 445, Cole-Parmer, Il, USA) in a $4 \mathrm{~L}$ jar for each incubation time. The volatile fatty acids (VFA) concentration were analyzed by using a gas chromatograph (Shimadzu-17A, Shimadzu, Kyoto, Japan). After collecting $15 \mathrm{~mL}$ of culture solutions in a $4 \mathrm{~L}$ jar for each incubation time, then $0.5 \mathrm{~mL}$ of saturated $\mathrm{HgCl}_{2}$ and $1 \mathrm{~mL}$ of $20 \%$ $\mathrm{HPO}_{3}$ were added. The culture solutions were separated via centrifugation at $1,250 \times \mathrm{g}$ for $15 \mathrm{~min}$, and supernatant was analyzed. The analysis condition is column : $30 \mathrm{~m} \times 0.25 \mathrm{~mm} \times 0.25 \mathrm{um}$, carrier gas : $37 \mathrm{~mL} / \mathrm{min}\left(\mathrm{He}: 7, \mathrm{H}_{2}: 15\right.$, and $\left.\mathrm{O}_{2}: 15\right)$, column flow rate $: 1 \mathrm{uL} / \mathrm{min}$, injection port tem- 
perature : $230^{\circ} \mathrm{C}$, detection port temperature $: 230^{\circ} \mathrm{C}$, and oven temperature $: 230^{\circ} \mathrm{C}\left(100^{\circ} \mathrm{C}-230^{\circ} \mathrm{C}\right.$ $\left.: 8^{\circ} \mathrm{C} / \mathrm{min}\right)$.

DM degradability was calculated on the basis of the weight difference before and after rumen incubation. Starch degradability was calculated based on the weight or differences in DM content and starch before and after ruminal incubation.

\section{Statistical analysis}

All the experimental results were analyzed by GLM Procedure of SAS (2004) 9.2 Software Package. Variance analysis was performed using the square sum of TYPE III, suitable for the unbalanced data among the four squares resulting from the SAS/GLM analysis. To investigate the effects of thickness of corn flakes produced in a PSC on fermentation characteristics, the following linear model was used to analyze the variance.

$$
\mathrm{Y}_{\mathrm{ijk} l}=\mu+\mathrm{TT}_{\mathrm{i}}+\mathrm{TM}_{\mathrm{j}}+\mathrm{B}_{\mathrm{k}}+(\mathrm{TT} \times \mathrm{TM})_{\mathrm{ij}}+(\mathrm{TT} \times \mathrm{B})_{\mathrm{ik}}+(\mathrm{TM} \times \mathrm{B})_{\mathrm{jk}}+\mathrm{e}_{\mathrm{ijk} \mathrm{k}}
$$

Where, $\mathrm{Y}_{\mathrm{ijk}}=$ individual observations, $\mu=$ overall mean, $\mathrm{TT}=$ effect of $\mathrm{i}$ th treatment ( 3 conditions), $\mathrm{TM}_{\mathrm{j}}=$ effect of $\mathrm{j}$ th incubation time $(\mathrm{j}=3,6,9,12$, and $24 \mathrm{~h}), \mathrm{B}_{\mathrm{k}}=$ effect of $\mathrm{k}$ th breed $(\mathrm{k}=$ Holstein, Hanwoo), $(\mathrm{TT} \times \mathrm{TM})_{\mathrm{ij}}=$ the interaction effects of $\mathrm{i}$ th treatment and $\mathrm{j}$ th incubation time, $(\mathrm{TT} \times \mathrm{B})_{\mathrm{ik}}$ $=$ the interaction effect of the $\mathrm{i}$ th treatment and the $\mathrm{k}$ th breed, $(\mathrm{TM} \times \mathrm{B})_{\mathrm{jk}}=$ the interaction effect of the $\mathrm{j}$ th incubation time and $\mathrm{k}$ th breed, $\mathrm{e}_{\mathrm{ijkl}}=$ random error.

Degradability of DM and starch were analyzed using the following linear model.

$$
\mathrm{Y}_{\mathrm{ijklm}}=\mu+\mathrm{TT}_{\mathrm{i}}+\mathrm{TM}_{\mathrm{j}}+\mathrm{B}_{\mathrm{k}}+(\mathrm{TT} \times \mathrm{TM})_{\mathrm{ij}}+(\mathrm{TT} \times \mathrm{B})_{\mathrm{ik}}+(\mathrm{TM} \times \mathrm{B})_{\mathrm{jk}}+\mathrm{A}(\mathrm{B})_{\mathrm{ik}}+\mathrm{e}_{\mathrm{ijk} \mathrm{km}}
$$

Where, $Y_{\mathrm{ijkl}}=$ individual observations, $\mu=$ overall mean, $\mathrm{TM}_{\mathrm{j}}=$ the effect of the $\mathrm{j}$ th incubation time $(\mathrm{j}=3,6,9,12$, and $24 \mathrm{~h}), \mathrm{B}_{\mathrm{k}}=$ the effect of $\mathrm{k}$ th breed $\left(\mathrm{k}=\right.$ Holstein, Hanwoo), $(\mathrm{TT} \times \mathrm{TM})_{\mathrm{ij}}=$ the interaction effect of $i$ th treatment and $j$ th incubation time, $(T T \times B)_{i k}=$ the interaction effect of $i$ th treatment and $\mathrm{k}$ th breed, $(\mathrm{TM} \times \mathrm{B})_{\mathrm{jk}}=$ the interaction effect of $\mathrm{j}$ th incubation time and $\mathrm{k}$ th breed, $\mathrm{A}(\mathrm{B})_{\mathrm{ik}}=$ the effect of $\mathrm{i}$ th animal ( 6 conditions) overlapped on the $\mathrm{k}$ the breed, $\mathrm{e}_{\mathrm{ij} \mathrm{jlm}}=$ random error.

Duncan's multiple range test was used to compare differences in parameter mean values, and the $t$-test was used to determine the effect of the breed. Significant differences were accepted if $p<0.05$.

\section{RESULTS}

\section{Characteristics of in vitro ruminal fermentation}

The least squares mean of fermentation characteristics on corn flake thickness are shown in Table 2. The rumen $\mathrm{pH}$ value was lower in $\mathrm{T} 1$ and $\mathrm{T} 2$ than in T3 groups $(p<0.01)$, and acetate concentration was higher in T1 than T2 and T3 groups $(p<0.05)$. Propionate concentration tended to increase with a reduction in corn flake thickness and was significantly higher in T1 than in T3 $p<$ 0.05 ). Total-volatile fatty acids (T-VFA) concentration was significantly higher in T1 than in T3 ( $p$ $<0.05)$ and was similar between $\mathrm{T} 1$ and $\mathrm{T} 2$.

The least squares mean of the breed in fermentation characteristics on corn flake thickness are shown in Table 3. In the case of Holstein cows, rumen $\mathrm{pH}$ value was significantly higher in T3 than in T2 $(p<0.05)$ and similar between T1 and T2. Acetate concentration was higher in T1 than T2 and T3 $(p<0.05)$; propionate, higher in T1 and T2 $(p<0.05)$ than in T3; butyrate, slightly but not significantly higher in T2 than T1 and T3. T-VFA concentration increased slightly, but not significantly, with a reduction in corn flake thickness. In the case of Hanwoo cows, the rumen $\mathrm{pH}$ 
Table 2. Least squares mean of in vitro ruminal parameters by the thickness of corn flakes using the pressurized steam chamber

\begin{tabular}{lcccc}
\hline \multirow{2}{*}{ Item } & \multicolumn{3}{c}{ Treatments $^{\text {1) }}$} & \multirow{2}{*}{ SEM } \\
\cline { 2 - 4 } & T1 & T2 & T3 & \\
\hline $\mathrm{pH}$ & $5.88^{\mathrm{b}}$ & $5.90^{\mathrm{b}}$ & $5.96^{\mathrm{a}}$ & 0.04 \\
Acetate $(\mathrm{mmol} / \mathrm{L})$ & $46.15^{\mathrm{a}}$ & $44.15^{\mathrm{b}}$ & $44.23^{\mathrm{ab}}$ & 2.24 \\
Propionate $(\mathrm{mmol} / \mathrm{L})$ & $23.84^{\mathrm{a}}$ & $23.54^{\mathrm{a}}$ & $22.29^{\mathrm{b}}$ & 1.22 \\
Butyrate $(\mathrm{mmol} / \mathrm{L})$ & $14.31^{\mathrm{NS}}$ & $14.57^{\mathrm{NS}}$ & $14.27^{\mathrm{NS}}$ & 9.70 \\
T-VFA $(\mathrm{mmol} / \mathrm{L})$ & $84.30^{\mathrm{a}}$ & $82.25^{\mathrm{ab}}$ & $80.79^{\mathrm{b}}$ & 3.28 \\
\hline
\end{tabular}

${ }^{1}$ Treatments : $\mathrm{T} 1<2.5 \mathrm{~mm}, \mathrm{~T} 2=2.5-3.0 \mathrm{~mm}$, and $\mathrm{T} 3>3.0 \mathrm{~mm}$.

${ }^{a, b}$ Means without same superscripts within a row are significantly different $(p<0.05)$.

SEM, standard error of the mean; NS, not significant; T-VFA, total volatile fatty acids

Table 3. Least squares mean of breed on in vitro ruminal parameters by the thickness of corn flakes using the pressurized steam chamber

\begin{tabular}{|c|c|c|c|c|c|}
\hline \multirow{2}{*}{ Item } & \multirow{2}{*}{ Breed } & \multicolumn{3}{|c|}{ Treatments $^{1)}$} & \multirow{2}{*}{ SEM } \\
\hline & & T1 & T2 & T3 & \\
\hline \multirow[t]{3}{*}{$\mathrm{pH}$} & Holstein & $5.86^{\mathrm{ab}}$ & $5.84^{b}$ & $5.90^{a}$ & 0.04 \\
\hline & Hanwoo & $5.91^{\mathrm{c}}$ & $5.95^{\mathrm{b}}$ & $6.03^{\mathrm{a}}$ & 0.03 \\
\hline & $\mathrm{Vd}^{2)}$ & $-0.05^{\mathrm{NS}}$ & $-0.11^{* *}$ & $-0.13^{\star \star}$ & \\
\hline \multirow[t]{3}{*}{ Acetate $(\mathrm{mmol} / \mathrm{L})$} & Holstein & $50.26^{a}$ & $45.78^{b}$ & $46.53^{b}$ & 2.60 \\
\hline & Hanwoo & $42.04^{\mathrm{NS}}$ & $42.51^{\mathrm{NS}}$ & $41.94^{\mathrm{NS}}$ & 1.87 \\
\hline & $\mathrm{Vd}$ & $8.22^{* *}$ & $3.27^{*}$ & $4.59^{*}$ & \\
\hline \multirow[t]{3}{*}{ Propionate $(\mathrm{mmol} / \mathrm{L})$} & Holstein & $26.51^{\mathrm{ab}}$ & $27.13^{a}$ & $25.23^{b}$ & 1.42 \\
\hline & Hanwoo & $21.16^{a}$ & $19.95^{\mathrm{ab}}$ & $19.34^{b}$ & 1.03 \\
\hline & $\mathrm{Vd}$ & $5.35^{\star *}$ & $7.18^{* *}$ & $5.89^{\star *}$ & \\
\hline \multirow[t]{3}{*}{ Butyrate $(\mathrm{mmol} / \mathrm{L})$} & Holstein & $15.60^{\mathrm{NS}}$ & $15.99^{\mathrm{NS}}$ & $15.47^{\mathrm{NS}}$ & 1.08 \\
\hline & Hanwoo & $13.02^{\mathrm{NS}}$ & $13.14^{\mathrm{NS}}$ & $13.07^{\mathrm{NS}}$ & 0.86 \\
\hline & $\mathrm{Vd}$ & $2.58^{* *}$ & $2.85^{\star *}$ & $2.40^{*}$ & \\
\hline \multirow[t]{3}{*}{ Total-VFA (mmol/L) } & Holstein & $92.38^{a}$ & $88.90^{\mathrm{ab}}$ & $87.24^{b}$ & 4.17 \\
\hline & Hanwoo & $76.22^{\mathrm{NS}}$ & $75.61^{\mathrm{NS}}$ & $74.35^{\mathrm{NS}}$ & 2.39 \\
\hline & $\mathrm{Vd}$ & $16.16^{\star \star}$ & $13.29^{\star \star}$ & $12.89^{\star *}$ & \\
\hline
\end{tabular}

${ }^{1)}$ Treatments : $\mathrm{T} 1<2.5 \mathrm{~mm}, \mathrm{~T} 2=2.5-3.0 \mathrm{~mm}$, and $\mathrm{T} 3>3.0 \mathrm{~mm}$.

${ }^{2)}$ Varietal difference: difference between Holstein and Hanwoo mean (Holstein - Hanwoo).

${ }^{a-c}$ Means without same superscripts within a row are significantly different $(p<0.05)$.

${ }^{*} p<0.05,{ }^{* *} p<0.01$.

SEM, standard error of the mean; NS, not significant; T-VFA, total volatile fatty acid.

value decreased with a reduction in corn flake thickness $(p<0.05)$. Acetate, butyrate, and T-VFA concentrations were slightly but not significantly higher in T2 than in T1 and T3. Propionate concentration was greater in $\mathrm{T} 1$ and $\mathrm{T} 2$ than in $\mathrm{T} 3(p<0.05)$.

Changes in rumen $\mathrm{pH}$ values and VFA concentrations based on the thickness of corn flakes produced using the PSC are shown in Table 4. The rumen $\mathrm{pH}$ value was significantly lower in T1 and $\mathrm{T} 2$ than in $\mathrm{T} 3$ at $12 \mathrm{~h}(p<0.05)$. Acetate and butyrate concentrations were not significantly different throughout the incubation time. Propionate concentration was significantly higher in T1 than in T2 and T3 at $3 \mathrm{~h}(p<0.05)$ and significantly higher in T2 than in T3 at incubation $12 \mathrm{~h}(p$ $<0.05)$. T-VFA concentrations were the highest in T1 from 6 to $24 \mathrm{~h}$, but there was no significant difference between treatments. 
Table 4. Changes in the in vitro ruminal $\mathrm{pH}$ values and volatile fatty acid concentrations by the thickness of corn flakes using the pressurized steam chamber

\begin{tabular}{|c|c|c|c|c|c|}
\hline \multirow{2}{*}{ Item } & \multirow{2}{*}{ Time (h) } & \multicolumn{3}{|c|}{ Treatments $^{1)}$} & \multirow{2}{*}{ SEM } \\
\hline & & T1 & T2 & T3 & \\
\hline \multirow[t]{4}{*}{$\mathrm{pH}$} & 3 & $6.68^{\mathrm{NS}}$ & $6.69^{\mathrm{NS}}$ & $6.68^{\mathrm{NS}}$ & 0.01 \\
\hline & 6 & $6.34^{\mathrm{NS}}$ & $6.35^{\mathrm{NS}}$ & $6.41^{\mathrm{NS}}$ & 0.02 \\
\hline & 12 & $5.20^{\mathrm{b}}$ & $5.20^{b}$ & $5.41^{\mathrm{a}}$ & 0.08 \\
\hline & 24 & $4.47^{\mathrm{NS}}$ & $4.51^{\mathrm{NS}}$ & $4.58^{\mathrm{NS}}$ & 0.04 \\
\hline \multirow[t]{4}{*}{ Acetate $(\mathrm{mmol} / \mathrm{L})$} & 3 & $29.81^{\text {NS }}$ & $27.76^{\mathrm{NS}}$ & $28.60^{\mathrm{NS}}$ & 1.65 \\
\hline & 6 & $39.22^{\mathrm{NS}}$ & $37.69^{\mathrm{NS}}$ & $35.34^{\mathrm{NS}}$ & 1.36 \\
\hline & 12 & $52.14^{\mathrm{NS}}$ & $49.44^{\mathrm{NS}}$ & $52.20^{\mathrm{NS}}$ & 2.38 \\
\hline & 24 & $82.24^{\mathrm{NS}}$ & $80.15^{\mathrm{NS}}$ & $79.67^{\mathrm{NS}}$ & 3.56 \\
\hline \multirow[t]{4}{*}{ Propionate $(\mathrm{mmol} / \mathrm{L})$} & 3 & $7.76^{\mathrm{NS}}$ & $8.55^{\mathrm{NS}}$ & $8.12^{\mathrm{NS}}$ & 0.51 \\
\hline & 6 & $17.07^{\mathrm{a}}$ & $14.40^{b}$ & $13.91^{b}$ & 0.84 \\
\hline & 12 & $26.84^{\mathrm{NS}}$ & $26.13^{\mathrm{NS}}$ & $24.78^{\mathrm{NS}}$ & 1.37 \\
\hline & 24 & $61.12^{\mathrm{ab}}$ & $63.43^{\mathrm{a}}$ & $59.49^{b}$ & 2.16 \\
\hline \multirow[t]{4}{*}{ Butyrate $(\mathrm{mmol} / \mathrm{L})$} & 3 & $7.63^{\mathrm{NS}}$ & $7.37^{\mathrm{NS}}$ & $8.11^{\mathrm{NS}}$ & 0.62 \\
\hline & 6 & $11.80^{\mathrm{NS}}$ & $12.02^{\mathrm{NS}}$ & $12.07^{\mathrm{NS}}$ & 0.59 \\
\hline & 12 & $16.58^{\mathrm{NS}}$ & $18.10^{\mathrm{NS}}$ & $16.74^{\mathrm{NS}}$ & 0.83 \\
\hline & 24 & $30.17^{\mathrm{NS}}$ & $30.41^{\mathrm{NS}}$ & $29.22^{\mathrm{NS}}$ & 1.85 \\
\hline \multirow[t]{4}{*}{ Total-VFA (mmol/L) } & 3 & $45.21^{\mathrm{NS}}$ & $43.68^{\mathrm{NS}}$ & $44.83^{\mathrm{NS}}$ & 1.74 \\
\hline & 6 & $68.10^{\mathrm{a}}$ & $64.10^{\mathrm{ab}}$ & $61.32^{b}$ & 2.03 \\
\hline & 12 & $95.56^{\mathrm{NS}}$ & $93.66^{\mathrm{NS}}$ & $93.72^{\mathrm{NS}}$ & 3.65 \\
\hline & 24 & $173.53^{\mathrm{NS}}$ & $174.09^{\mathrm{NS}}$ & $168.48^{\mathrm{NS}}$ & 5.70 \\
\hline
\end{tabular}

${ }^{1)}$ Treatments : $\mathrm{T} 1<2.5 \mathrm{~mm}, \mathrm{~T} 2=2.5-3.0 \mathrm{~mm}$, and $\mathrm{T} 3>3.0 \mathrm{~mm}$

a,b Means without same superscripts within a row are significantly different $(p<0.05)$

SEM, standard error of the mean; NS, not significant; T-VFA, total volatile fatty acid.

\section{In situ degradability of nutrient}

The least squares mean of DM and starch degradability based on corn flake thickness are shown in Table 5. DM and starch degradability increased significantly with a reduction in corn flake thickness $(p<0.01)$.

The least squares mean of the breed in the DM and starch degradability based on corn flake thickness are shown in Table 6. In the case of Holstein cows, DM degradability increased significantly with a reduction in corn flake thickness $(p<0.01)$. Starch degradability was significantly higher in T1 than in T3 $(p<0.01)$ and similar between T1 and T2. In Hanwoo cows, DM and starch degradability increased significantly with a reduction in corn flake thickness $(p<0.01)$. Regardless of the breed, DM and starch degradability increased significantly with a reduction in corn

Table 5. Least squares mean of ruminal dry matter and starch degradability by the thickness of corn flakes using the pressurized steam chamber

\begin{tabular}{lcccc}
\hline \multirow{2}{*}{ Item } & \multicolumn{3}{c}{ Treatments $^{\text {1) }}$} & \multirow{2}{*}{ SEM } \\
\cline { 2 - 4 } & T1 & T2 & T3 & \\
\hline Dry matter (\%) & $37.50^{\mathrm{a}}$ & $35.73^{\mathrm{b}}$ & $26.17^{\mathrm{c}}$ & 1.14 \\
Starch (\%) & $49.23^{\mathrm{a}}$ & $47.20^{\mathrm{b}}$ & $41.41^{\mathrm{c}}$ & 0.86 \\
\hline
\end{tabular}

${ }^{1)}$ Treatments : $\mathrm{T} 1<2.5 \mathrm{~mm}, \mathrm{~T} 2=2.5-3.0 \mathrm{~mm}$, and $\mathrm{T} 3>3.0 \mathrm{~mm}$.

${ }^{a-c}$ Means without same superscripts within a row are significantly different $(p<0.01)$

SEM, standard error of the mean. 
Ahn et al.

Table 6. Least squares mean of breed on ruminal dry matter and starch degradabilities by the thickness of corn flakes using the pressurized steam chamber

\begin{tabular}{|c|c|c|c|c|c|}
\hline \multirow{2}{*}{ Item } & \multirow{2}{*}{ Breed } & \multicolumn{3}{|c|}{ Treatments $^{1)}$} & \multirow{2}{*}{ SEM } \\
\hline & & T1 & T2 & T3 & \\
\hline \multirow[t]{3}{*}{ Dry matter (\%) } & Holstein & $39.24^{a}$ & $36.99^{b}$ & $27.72^{c}$ & 1.13 \\
\hline & Hanwoo & $35.76^{a}$ & $34.47^{b}$ & $24.63^{c}$ & 1.14 \\
\hline & $V d^{2)}$ & $3.48^{* *}$ & $2.52^{* \star}$ & $3.09^{\star *}$ & \\
\hline \multirow[t]{3}{*}{ Starch (\%) } & Holstein & $50.66^{a}$ & $48.23^{a b}$ & $42.84^{b}$ & 0.93 \\
\hline & Hanwoo & $47.81^{a}$ & $46.16^{b}$ & $39.97^{c}$ & 0.80 \\
\hline & $\mathrm{Vd}$ & $2.85^{\star *}$ & $2.07^{* *}$ & $2.87^{* *}$ & \\
\hline
\end{tabular}

${ }^{1)}$ Treatments : $\mathrm{T} 1<2.5 \mathrm{~mm}, \mathrm{~T} 2=2.5-3.0 \mathrm{~mm}$, and $\mathrm{T} 3>3.0 \mathrm{~mm}$.

${ }^{2)}$ Varietal difference: difference between Holstein and Hanwoo mean (Holstein - Hanwoo).

${ }^{a-c}$ Means without same superscripts within a row are significantly different $(p<0.01)$.

${ }^{* *} p<0.01$.

SEM, standard error of the mean

flake thickness $(p<0.01)$ but was similar between T1 and T2.

Changes in DM and starch degradability based on corn flake thickness are shown in Table 7. Throughout the incubation time, DM and starch degradability were significantly lower in T3 than in T1 and T2 $(p<0.01)$ but were similar between T1 and T2.

\section{DISCUSSION}

\section{Characteristics of in vitro ruminal fermentation}

In general, increase in thickness or density of corn flakes can improve the availability of corn flakes in the rumen [16,17]. Zinn et al. [2] reported that corn flake density varies depending on the production conditions (species, country of origin, climate, harvest time, etc.) of the corn, size of the chamber, loss of moisture, grain handling, etc.; however, corn flake thickness can be maintained constant. Therefore, corn flake thickness is considered an important factor to control the quality of corn flakes.

In the present study, a reduction in corn flake thickness was accompanied by an increase in gelatinization. This result is concurrent with that of Wang et al. [18], wherein a reduction in corn flake

Table 7. Changes in ruminal dry matter and starch degradabilities by the thickness of corn flakes using the pressurized steam chamber

\begin{tabular}{lccccc}
\hline \multirow{2}{*}{ Item } & Time (h) & \multicolumn{3}{c}{ Treatments $^{1)}$} & \multirow{2}{*}{ SEM } \\
\cline { 3 - 5 } & & T1 & T2 & T3 & \\
\hline Dry matter (\%) & 3 & $27.33^{\mathrm{a}}$ & $26.09^{\mathrm{a}}$ & $17.55^{\mathrm{b}}$ & 0.99 \\
& 6 & $33.75^{\mathrm{a}}$ & $31.56^{\mathrm{a}}$ & $22.41^{\mathrm{b}}$ & 1.03 \\
& 12 & $43.19^{\mathrm{a}}$ & $41.11^{\mathrm{a}}$ & $29.30^{\mathrm{b}}$ & 1.16 \\
& 24 & $62.11^{\mathrm{a}}$ & $59.62^{\mathrm{a}}$ & $48.00^{\mathrm{b}}$ & 1.35 \\
\hline Starch (\%) & 3 & $38.37^{\mathrm{a}}$ & $37.21^{\mathrm{a}}$ & $33.26^{\mathrm{b}}$ & 0.42 \\
& 6 & $44.71^{\mathrm{a}}$ & $42.58^{\mathrm{b}}$ & $37.72^{\mathrm{c}}$ & 0.56 \\
& 12 & $52.13^{\mathrm{a}}$ & $50.38^{\mathrm{a}}$ & $44.35^{\mathrm{b}}$ & 0.79 \\
& 24 & $77.31^{\mathrm{a}}$ & $73.67^{\mathrm{a}}$ & $62.86^{\mathrm{b}}$ & 1.70 \\
\hline
\end{tabular}

${ }^{1)}$ Treatments : $\mathrm{T} 1<2.5 \mathrm{~mm}, \mathrm{~T} 2=2.5-3.0 \mathrm{~mm}$, and $\mathrm{T} 3>3.0 \mathrm{~mm}$.

${ }^{a-c}$ Means without same superscripts within a column are significantly different $(p<0.01)$.

SEM, standard error of the mean. 
density was accompanied with an increase in the degree of gelatinization.

In the present study, a reduction in corn flake thickness led to reduced ruminal $\mathrm{pH}$ and increased volatile fatty acid (especially propionate) concentration. This result could be due to the increase in ruminal degradation and fermentation of starch owing to the increased gelatinization of corn flake starch. In addition, the present finding is concurrent with that of Reinhardt et al. [7], wherein a reduction in corn flake density was accompanied by a reduction in ruminal $\mathrm{pH}$; however, the volatile fatty acid concentration increased.

Furthermore, a reduction in corn flake thickness was accompanied with a reduction in ruminal $\mathrm{pH}$ and an increased possibility of acute acidosis, which could adversely affect the health and productivity of the cattle [19]. Zinn [20] reported a reduction in feed efficiency resulting from feeding of corn flakes of $1.68 \mathrm{~mm}$ thickness compared to corn flakes of $1.83 \mathrm{~mm}$ and $2.23 \mathrm{~mm}$ thickness, owing to digestive dysfunction. In the present study, differences in $\mathrm{pH}$ and volatile fatty acid concentration upon feeding less than $2.5 \mathrm{~mm}$ thick and 2.5-3.0 mm thick corn flakes were small; therefore, the optimal corn flake thickness produced using the pressurized chamber was estimated to be $2.5-3.0 \mathrm{~mm}$.

\section{In situ degradability of nutrient}

Schwandt [21] reported that a reduction in corn flake thickness is accompanied with a reduction in density and an increase in the amount of digestible starch. Zinn et al. [2] reported that corn flake thickness is closely associated with the solubility and enzyme reactivity of starch. In the present study, concurrent with previous reports, the thinning of corn flakes improved the dry matter and starch degradability probably owing to an increase in digestible starch in the rumen owing to increased solubility of starch with an increase in gelatinization (Fig. 1). Son et al. [6] reported that an increase in the dry matter and starch digestibility owing to thinning of corn flakes was attributable to the ease of ruminal microbial penetration into the corn flakes, the increase in $\alpha$-starch, and destruction of the protein membrane around starch. These results are concurrent with the present results wherein the thinner the corn flakes, the higher the degradability of the dry matter and starch. In addition, the present findings are also similar to those of Swingle et al. [22], wherein starch degradability was increased with a reduction in corn flake density from $421 \mathrm{~g} / \mathrm{L}$ to $257 \mathrm{~g} / \mathrm{L}$.

However, in the present study, owing to the slight difference in gelatinization and starch degradability between corn flakes less than $2.5 \mathrm{~mm}$ and those measuring $2.5-3.0 \mathrm{~mm}$, proper thickness is more important than too thin processing for quality control of corn flakes.

Plascencia and Zinn [5] reported that a reduction in corn flake thickness (1.66, 1.88, and 2.45 $\mathrm{mm}$ ) is accompanied by an increase in solubility and digestibility of starch and an increase in the feed value of corn flakes; however, the optimal thickness of corn flakes was 1.88-2.45 mm. Zinn [23] reported that on comparing the feed values between corn flakes measuring $0.95 \mathrm{~mm}$ and $1.35 \mathrm{~mm}$, there was no obvious benefit (improvement in feed value) for reducing corn flake thickness to less than $1.3 \mathrm{~mm}$. In addition, to reduce corn flake thickness, the production costs of gas and electricity increased owing to overloading of the rolls [24]. Reinhardt et al. [7] reported that, compared to the corn flake density was $361 \mathrm{~g} / \mathrm{L}$, production cost per ton of corn flakes increased by $26.9 \%$ and $67.5 \%$ at 322 and $238 \mathrm{~g} / \mathrm{L}$, respectively. Furthermore, as the space between the rolls is reduced to reduce corn flake thickness, the rate of loss of corn is increased and the value of the corn flakes may be reduced owing to cracking or increased flour production. Thus, considering the difference in ruminal starch degradability and economic feasibility between T1 $(<2.5 \mathrm{~mm})$ and T2 $(2.5-3.0 \mathrm{~mm})$, the optimal corn flake thickness upon using the PSC is recommended at $2.5-3.0 \mathrm{~mm}$.

On the other hand, rumen fermentation and digestion are influenced by the type of microorganism, feed, age, livestock, and body weight [25], and it has been reported that the rumen fermen- 
tation rate increases as body weight increases [26]. In this study, the tendency was the same among the varieties (Holstein and Hanwoo) according to the corn flake thickness treatment produced in PSC, but it was considered that the weight and microbial groups had an effect on the differences among varieties. Bartocci et al. [27] reported a difference in the rumen passage rate of feed between livestock (buffalo, bull and goat), and Voigt et al. [28] reported that dairy cattle showed a more efficient rumen digestion process compared to Galloway and Highland bull. Therefore, in general, it is considered that the treatment effect according to corn flake thickness can be more effectively applied in Holstein, which has a higher weight and digestibility than Hanwoo.

\section{CONCLUSION}

In this study, the thickness of corn flakes produced using a pressurized steam chamber was found to significantly affect gelatinization, rumen $\mathrm{pH}$, concentration of propionic acid, and degradability of dry matter and starch. As the corn flake thickness decreased, energy availability improved, but the greater part of result between the thickness of $<2.5 \mathrm{~mm}$ and $2.5-3.0 \mathrm{~mm}$ was not significantly different, and the excessive thickness reduction may cause problems such as a rapid decrease in rumen $\mathrm{pH}$ and an increase in processing cost. Thus, considering the production efficiency and economic feasibility, the optimal thickness of corn flakes produced in a PSC is recommended to be $2.5-3.0$ $\mathrm{mm}$.

\section{REFERENCES}

1. Ahn JS. Study on optimal processing condition of the pressurized steam chamber and feed value evaluation for quality improvement of corn flaked [Ph.D. dissertation]. Chuncheon, Korea: Kangwon National University; 2017.

2. Zinn RA, Owens FN, Ware RA. Flaking corn: processing mechanics, quality standards, and impacts on energy availability and performance of feedlot cattle.J Anim Sci. 2002;80:1145-56.

3. Hales KE, McMeniman JP, Leibovich J, Vasconcelos JT, Quinn MJ, May ML, et al. Effects of varying bulk densities of steam-flaked corn and dietary roughage concentration on in vitro fermentation, performance, carcass quality, and acid-base balance measurements in finishing steers. J Anim Sci. 2010;88:1135-47.

4. Schwandt EF, Hubbert ME, Thomson DU, Vahl C, Bartle SJ, Reinhardt CD. Flake density, roll diameter, and flake moisture all influence starch availability of steam-flaked corn. Kans Agric Exp Stn Res Reports. 2017;31:22.

5. Plascencia A, Zinn RA. Influence of flake density on the feeding value of steam-processed corn in diets for lactating cows.J Anim Sci. 1996;74:310-6.

6. Son KN, Kim YK, Lee SK, Kim HS. The effects of processing methods of corn on in vitro DM digestibility and in sacco degradability in rumen. Korean J Anim Sci Technol. 2003;45:433-42.

7. Reinhardt CD, Brandt RT, Eck TP, Titgemeyer EC. Performance, digestion, and mastication efficiency of Holstein steers fed whole or processed corn in limit- or full-fed growing-finishing systems. J Anim Sci. 1998;76:1778-88.

8. Brown MS, Krehbiel CR, Duff GC, Galyean ML, Hallford DM, Walker DA. Effect of degree of corn processing on urinary nitrogen composition, serum metabolite and insulin profiles, and performance by finishing steers.J Anim Sci. 2000;78:2464-74.

9. Swingle RS. Impact of sorghum grain flake density on feedlot performance. In: Proceedings of Southwest Nutrition and Management Conference; 1992; Tucson, AZ. p. 55-63.

10. Zinn RA. Influence of processing on the comparative feeding value of barley for feedlot cattle. 
J Anim Sci. 1993;71:3-10.

11. McDougall EI. Studies on ruminant saliva. 1. the composition and output of sheep's saliva. J Biochem. 1948;43:99-109.

12. AOAC [Association of Official Analytical Chemists]. Official method of analysis of AOAC. 15th ed. Washington, DC: AOAC; 1990.

13. Goering HK, Van Soest PJ. Forage fiber analysis: apparatus, reagents, procedures, and some applications. Washington, DC: Agricultural Research Service, U.S. Department of Agriculture; 1979. Agriculture Handbook. No. 379.

14. Ministry of Agriculture, Food and Rural Affairs. Feed standard analysis method. Sejong, Korea: Ministry of Agriculture, Food and Rural Affairs; 2017. p. 310-1.

15. Ministry of Food and Drug Safety. Korean food standards codex. Cheongju, Korea: Ministry of Food and Drug Safety; 2016. p. 279.

16. Theurer CB, Lozano O, Alio A, Delgado-Elorduy A, Sadik M, Huber JT, et al. Steam-processed corn and sorghum grain flaked at different densities alter ruminal, small intestinal, and total tract digestibility of starch by steers.J Anim Sci. 1999;77:2824-31.

17. Zinn RA, Barreras A, Corona L, Owens FN, Plascencia A. Comparative effects of processing methods on the feeding value of maize in feedlot cattle. Nutr Res Rev. 2011;24:183-90.

18. Wang Y,McAllister TA. Investigation of exogenous fibrolytic enzyme activity on barley straw using in vitro incubation.J Anim Sci. 2002;80:316.

19. Domby EM, Anele UY, Gautam KK, Hergenreder JE, Pepper-Yowell AR, Galyean ML. Interactive effects of bulk density of steam-flaked corn and concentration of Sweet Bran on feedlot cattle performance, carcass characteristics, and apparent total tract nutrient digestibility. J Anim Sci. 2014;92:1133-43.

20. Zinn RA. Influence of steaming time on site of digestion of flaked corn in steers. J Anim Sci. 1990;68:776-81.

21. Schwandt EF. Grain processing considerations influencing starch digestion and performance of feedlot cattle [Ph.D. dissertation]. Manhattan, NY: Kansas State University; 2015.

22. Swingle RS, Eck TP, Theurer CB, De la Llata M, Poore MH, Moore JA. Flake density of steam-processed sorghum grain alters performance and sites of digestibility by growing-finishing steers. J Anim Sci. 1999;77:1055-65.

23. Zinn RA. Influence of flake thickness on the feeding value of steam-rolled wheat for feedlot cattle. J Anim Sci. 1994;72:21-8.

24. Drouillard J, Reinhardt C. Flaked grain variables: control points and evaluation of flaked grains. In: Proceedings of the Cattle Grain Processing Symposium; 2016; Tulsa, Oklahoma. p. 81-7.

25 Hungate RE. The rumen and its microbes. 1st ed. New York, NY: Academic Press; 1966. p. 533-40.

26. Hungate RE, Phillips GD, Hungate DP, MacGregor A. A comparison of the rumen fermentation in European and Zebu cattle.J Agric Sci. 1960;54:196-201.

27. Bartocci S, Amici A, Verna M, Terramoccia S, Martillotti F. Solid and fluid passage rate in buffalo, cattle and sheep fed diets with different forage to concentrate ratios. Livest Prod Sci. 1997;52:201-8.

28. Voigt J, Jentsch W, Kuhla S, Matthes HD, Derno M. Rumen fermentation and retention time of the digesta in growing cattle of the breeds Black-White Dairy Cattle, Galloway, and Highland. Arch Anim Breed. 2000;43:609-20. 